\title{
Plant nutrition and soil fertility: synergies for acquiring global green growth and sustainable development
}

\author{
Jan K. Schjoerring (1) • Ismail Cakmak • Philip J. White
}

Received: 5 November 2018 / Accepted: 22 November 2018/Published online: 3 December 2018

(C) Springer Nature Switzerland AG 2018

\section{Introduction}

This Special Issue of Plant and Soil presents highlights from the XVIII International Plant Nutrition Colloquium (IPNC), which was held from 21 to 24 August 2017 in Copenhagen, Denmark. The main theme of the meeting was Plant Nutrition for Global Green Growth. This theme was chosen to address some of the huge challenges associated with sustainable intensification of future global food production: (i) Green growth must be sufficient to produce more food in the next 50 years than in all of human history; (ii) Green growth must occur under the added pressures of climate change, water insecurity, land use changes, and soil degradation; and (iii) Best available

Responsible Editor: Hans Lambers.

J. K. Schjoerring $(\bowtie)$

Department of Plant and Environmental Sciences, Faculty of Science, University of Copenhagen, Copenhagen, Denmark e-mail: jks@plen.ku.dk

I. Cakmak

Biological Sciences and Bioengineering Program, Faculty of Engineering and Natural Sciences, Sabanci University Tuzla, Istanbul, Turkey

e-mail: cakmak@sabanciuniv.edu

\section{P. J. White}

Ecological Sciences Group, The James Hutton Institute, Dundee, Scotland

e-mail: Philip.White@hutton.ac.uk guidance and recommendations to farmers remain largely empirical rather than mechanistic.

\section{Sustainable management of soil fertility for crop production}

It has been estimated that $60 \%$ of cultivated soils suffer from growth-limiting problems, with both deficiencies and toxicities of mineral nutrients occurring globally (Cakmak 2002). A crucial aspect of plant nutrition is therefore to preserve the fertility of soils so that they can deliver nutrients at the right time and in the right quantity for growing plants (Johnston and Bruulsema 2014; Withers et al. 2018). Nutrient supply and plant growth are very frequently constrained by adverse soil conditions affecting parameters such as soil $\mathrm{pH}$ and redox state, which impact the phyto-availability of mineral nutrients and the concentrations of toxic elements in the soil solution (White and Greenwood 2013). Assessing the size of the phyto-available pool of nutrients is a fundamental challenge in plant nutrition (Tandy et al. 2012; Mason et al. 2013). It is, however, not only soil properties that determine the capability of soils to deliver nutrients. Soils also need to sustain root growth so that the growing plants can capture a sufficient proportion of the available nutrients (White et al. 2013ab). In this context, interaction with the soil microbiome, including mycorrhizae, is important (Richardson et al. 2017; Campos et al. 2018; Svenningsen et al. 2018). 
This IPNC Special Issue begins with a comprehensive and informative Marschner Review by Hallama et al. (2018), who analyse and discuss the role of cover crops and soil microorganisms (especially mycorrhizae) and their management in phosphorus $(\mathrm{P})$ nutrition of main crops, addressing also related mechanistic aspects and the major drivers of the $\mathrm{P}$ cycling in agricultural systems.

In order to sustain soil fertility so that sufficient amounts of nutrients can be delivered to growing plants, mineral nutrients are added as inorganic or organic fertilisers. Results from a long-term fertilization trial conducted in Denmark by van der Bom et al. (2018), involving application of various NPK fertilizers and animal slurry, highlight the importance of balanced fertilization in maintaining (i) high and stable crop productivity, (ii) adequate levels of soil nutrient availability, and (iii) efficient use of nutrients by crop plants. It is also concluded that direct carbon inputs from animal slurry are more effective drivers for increasing soil carbon concentrations than mineral fertilizer applications (van der Bom et al. 2018).

Fertiliser applications must be optimised in order to limit costs and restrict environmental damage. A common management strategy is based on the "Five Rs": to apply the right fertilisers at the right time in the right rate and at the rate place, also recycling nutrients where possible (Johnston and Bruulsema 2014; Withers et al. 2018). In recent years there has been increasing interest in using industrial and municipal waste streams as a source of phosphorus $(\mathrm{P})$ for use in agriculture. Struvite $\left(\mathrm{MgNH}_{4} \mathrm{PO}_{4} \cdot 6 \mathrm{H}_{2} \mathrm{O}\right)$ is a well-known P-rich precipitate originating from sewerage. Robles-Aguilar et al. (2018) used struvite as an alternative $\mathrm{P}$ fertilizer and compared its effects with a soluble $\mathrm{P}$ fertilizer $\left(\mathrm{KH}_{2} \mathrm{PO}_{4}\right)$ as a $\mathrm{P}$ source for narrow-leaf lupine. Their results indicate that the efficiency of P-fertiliser uptake by plants is much greater for struvite than from the soluble $P$ fertilizer in both acidic and alkaline conditions. Struvite behaved as a slow-release P fertilizer, and plants were able to use struvite effectively by modifying their rhizospheres through the release of carboxylates and by altering root morphological properties (for example by increasing specific root length).

Methods to diagnose crop nutrient deficiencies are valuable tools to ensure that sufficient fertiliser is applied in a timely manner to crops (van Maarschalkerweerd and Husted 2015). In order to cope with low or variable nutrient phyto-availability it is essential to develop new diagnostic tools that allow timely detection and correction of nutrient deficiencies in the field. Measurement of chlorophyll $a$ fluorescence provides a rapid and noninvasive probe of plant photo-chemistry, reflecting the key functions and bioactive pools of nutrients such as manganese and phosphorus in photosynthesis (Frydenvang et al. 2015; Schmidt et al. 2016; Carstensen et al. 2018a). This knowledge of physiology can be used to determine crop needs and to ensure optimal timing of fertiliser applications. An example of this is presented by Carstensen et al. (2018b) who were able to prevent irreversible damage to seedling growth, tiller development and grain yield in spring barley by using chlorophyll $a$ fluorescence measurement to correct $\mathrm{P}$ deficiency by application of $\mathrm{P}$ fertilizer.

When a nutrient deficiency is diagnosed, whether by physiological responses, visible symptoms or tissue analysis, it must be rectified. For this purpose, foliar applications of the required nutrient can be an effective approach, especially when crops are cultivated on soils in which the phyto-availabilty of mineral nutrients declines rapidly after the application of fertilizers. Addition of surfactants into foliar spray solutions improves their leaf coverage, and prevents droplets drying rapidly, thereby contributing to better absorption by plants. Januszkiewicz et al. (2018) used ZnIDHA, a new foliar Zn-fertilizer, and studied how three different surfactants affected leaf coverage and evaporation of ZnIDHA droplets. The tested surfactants greatly improved wettability of the leaf surface with the spray solution through a strong capillary effect. Of the tested surfactants, trisiloxane resulted in the greatest leaf coverage.

\section{Crop production on soils with unfavourable $\mathrm{pH}$ or low nutrient phytoavailability}

Crop production is often restricted by the $\mathrm{pH}$ of the soil solution, which determines the availability of mineral nutrients and exposure to toxic elements (Mueller et al. 2012; White et al. 2013a; Rengel 2015). Crop production on acid soils is generally limited by excessive $\mathrm{Al}^{3+}$ and $\mathrm{Mn}^{2+}$ concentrations, and low phyto-availability of $\mathrm{K}, \mathrm{P}, \mathrm{Mg}, \mathrm{Ca}$ or Mo. On alkaline and calcareous soils, crop production is generally limited by low phytoavailability of the micronutrients $\mathrm{Fe}, \mathrm{Zn}, \mathrm{Mn}$ and $\mathrm{Cu}$. Furthermore, crop yields of low input agriculture are generally limited by the phyto-availability of N, K, P or S. Crop production on less-fertile, acid or alkaline soils can be improved by management strategies that rectify soil $\mathrm{pH}$ and increase the phyto-availability of nutrients 
or the cultivation of crop genotypes with greater tolerance of these conditions (White et al. 2012, 2013b; Rengel 2015; Holland et al. 2018; Ryan 2018).

Genotypes of various crops tolerating the constraints of acid and alkaline soils have been developed over many years (Fageria et al. 2011; Abdallah et al. 2017; Ryan 2018). In addition, there has been a recent effort to develop crop genotypes with greater nutrient use efficiencies, either by selecting for these characters directly or breeding for component traits that optimise the physiological use of nutrients within the plant, for example by effective redistribution between senescent and developing tissues, or the acquisition of nutrients, such as the anatomical, morphological and biochemical traits of root systems (White et al. 2013ab; Wissuwa et al. 2016; Wang et al. 2018). In this issue, Kekulandara et al. (2018) report the results of field studies of 44 rice genotypes grown widely in Sri Lanka. The field studies were conducted at fertile and less-fertile sites to identify traits enabling greater production on less fertile soils. It was observed that grain dry weight (DW) yield was positively correlated with shoot N, P and K contents irrespective of soil fertility, and it was concluded that the ability of a genotype to acquire nutrients is a major constraint to grain production in rice. In a complimentary study, Li et al. (2018) have studied the consequences of root traits for $\mathrm{P}$ acquisition, growth and competition between crop genotypes. They compared the responses of seedlings of two maize genotypes bred in nutrient-rich (Xianyu335; XY335) and nutrient-poor (Huangmaya; HMY) environments to a limited homogeneous or heterogeneous $\mathrm{P}$ supply, as inorganic and organic forms, when grown in monoculture and when grown together. The maize genotypes differed in their root proliferation, mycorrhizal colonisation and release of phosphatases and phytases into soil, which are likely to affect their acquisition of inorganic phosphate (Pi) and organic P-compounds, respectively. The authors observed that HMY had a smaller response than XY335 in root morphology, but a greater response in biochemical traits, to P-limited environments; and that HMY had a competitive advantage (for biomass production) over XP335 when grown in mixtures in homogenous $\mathrm{P}$ environments, whereas the opposite was true in heterogeneous $\mathrm{P}$ environments. These observations could inform the choice of maize genotypes for low input and mixed-genotype cropping systems.

Management strategies that improve the phytoavailability of nutrients are fundamental to sustainable agricultural production. It has been reported that excess Pi-fertiliser applications can compromise plant $\mathrm{Zn}$ nutrition and, thereby, reduce crop yields, although the precise nature of these interactions remain unclear (Chen et al. 2018; Pongrac et al. 2018). According to Ova et al. (2015) the detrimental effect of increasing P supply on root $\mathrm{Zn}$ uptake seems to be mycorrhiza-dependent. In this Special Issue, two studies have described the contrasting effects of different soil types on the interactions between Pfertilisers and $\mathrm{Zn}$-fertilisers on the mineral nutrition of crops (Chen et al. 2018; Pongrac et al. 2018). Chen et al. (2018) grew wheat in the glasshouse in acid and calcareous soils and compared the effects of increasing rates of Pi-fertiliser application on the biomass and acquisition of $\mathrm{Zn}$ and $\mathrm{P}$ at stem elongation. They report that, although the greatest shoot biomass was similar in both soils and achieved with the largest Pi-fertiliser application rates, increasing the rate of Pi-application reduced plant $\mathrm{Zn}$ acquisition and that this effect occurred at a lower Pifertiliser application rate in the calcareous soil than in the acid soil. However, the relationships between phytoavailable $\mathrm{P}$ and $\mathrm{Zn}$ concentrations in the soil and shoot Zn concentrations differed between soils. A similar conclusion was made by Pongrac et al. (2018), who grew cabbage in the glasshouse in three soils with contrasting properties and compared different combinations of rates of Pi-fertiliser and $\mathrm{Zn}$-fertiliser on the biomass and shoot mineral composition of seedlings. Pongrac et al. (2018) report that shoot concentrations of $\mathrm{P}, \mathrm{K}, \mathrm{S}, \mathrm{Ca}, \mathrm{Mg}, \mathrm{Mn}$ and $\mathrm{Zn}$ in cabbage were affected more by soil type than by $\mathrm{P}$ and $\mathrm{Zn}$ amendments and that increasing Pi-fertiliser additions did not reduce shoot $\mathrm{Zn}$ concentration, but that the relationships between phyto-available $\mathrm{P}$ and $\mathrm{Zn}$ concentrations in the soil and shoot $\mathrm{Zn}$ concentrations differed between soils. These observations have implications for soil-specific fertilisation strategies for both crop production and the biofortification of edible crops with mineral elements for human and livestock nutrition.

Soil acidification has consequences for nutrient cycles, soil structure and chemical composition, biodiversity and agricultural productivity (Goulding 2016; Holland et al. 2018). Soil acidification in agricultural systems can be substantial (Guo et al. 2010), but it can be managed by liming, which has additional benefits for soil health (Goulding 2016; Holland et al. 2018). Acidification in agricultural soils is often a consequence of the use of urea or ammonium-based N-fertilisers (Goulding 2016). In this Special Issue, Hao et al. (2018) describe a field experiment to quantify the 
processes contributing to soil acidification in a wheatmaize double cropping system fertilised with urea on a moderately-acid Cambisol in southern China. They report that the uptake of base cations by crops contributed most to soil acidification, with ammonia emissions also contributing significantly. The leaching of bicarbonate was also appreciable, but there was limited nitrate leaching in this system.

Considerable research has been undertaken to develop crop genotypes for acid soils and a particular focus has been their tolerance of $\mathrm{Al}$ and $\mathrm{Mn}$ (Fageria et al. 2011; Ryan 2018). However, comparatively little research has been undertaken to develop crop genotypes suitable to alkaline and calcareous soils. In this Special Issue, Ding et al. (2018) describe an experiment in which two calcicole and two calcifuge Lupinus species were grown in river sand supplemented with a complete nutrient supply but different amounts of $\mathrm{K}_{2} \mathrm{SO}_{4}, \mathrm{KOH}$, $\mathrm{CaSO}_{4}$ and $\mathrm{CaCO}_{3}$ to manipulate $\mathrm{pH}$ and $\mathrm{Ca}$ supply independently. This experiment revealed that tolerance of high $\mathrm{pH}$, which improves root growth and the acquisition of mineral nutrients, was the key factor determining the tolerance of Lupinus species to calcareous soils rather than an excess Ca supply.

\section{The role of mineral elements in physiological adaptation to adverse environments}

Adverse soil conditions or unfavourable climatic conditions are associated with a range of physiological adaptations. Ensuring a proper nutrient supply can alleviate some of the most serious constraints to plant productivity associated with many stress conditions (Dwivedi et al. 2016). Ma et al. (2018) show in this special issue that the supply of potassium $(\mathrm{K})$ can increase grain set and yields in wheat under frost. This is the case, because the improved plant $\mathrm{K}$ status allows the wheat plants to better maintain physiological functions such as cell osmoregulation, plant photosynthesis and anti-oxidative defense (see also Traenkner et al. 2018). Plant K requirement at frost prone sites may thus be greater than at sites with low risk of frost damage (Ma et al. 2018). Boron deficiency is one of the major abiotic stresses affecting a range of crop species with serious negative effects on metabolism and productivity (Cakmak and Römheld 1997; Brown et al. 2002; Liu et al. 2015). Among the crops particularly affected by B deficiency are citrus crops. Wu et al. (2018) show in this Special
Issue resupply may alleviate the negative effects of B deficiency on root growth in the citrus rootstock Trifoliate orange by restoring central metabolites such as proline, myo-inositol and 6-deoxy-D-glucose. This provides new insight into the relationship between root growth and B resupply, which may contribute to new boron application strategies in citrus crops.

Expected increases in atmospheric $\mathrm{CO}_{2}$ and air temperature in the future may greatly influence the demand of crop plants for mineral nutrients. By growing the plants in predicted future climate conditions (i.e. $700 \mu \mathrm{mol} \mathrm{mol}{ }^{-1} \mathrm{CO}_{2}$ and $3{ }^{\circ} \mathrm{C}$ temperature rise), Asif et al. (2018) demonstrate a dramatic reduction in wheat maturation time. Plants exposed to a predicted future climate also responded with a significant reduction in biomass as well as in grain yield due to reduced number of spikes. The study concluded that adequate $\mathrm{N}$ and $\mathrm{Zn}$ supplies were essential to sustain crop performance in a changing climate with elevating atmospheric $\mathrm{CO}_{2}$ and rising global temperatures. This Special Issue also reports interesting results on the effects of metal hyperaccumulator and excluder metallophytes on soil microbial properties and soil physico-chemical characteristics both in the rhizosphere and in bulk soils at a mining site in China (Yang et al. 2018). Microbial biomass carbon and basal respiration rates were found to be higher in the rhizosphere soil of metal hyperaccumulator compared to the metal excluders. The concentration of available heavy metals in the rhizosphere of the metal hyperaccumulator (i.e., S. alfredii) showed a significant decrease, leading to suitable conditions for the survival of soil microorganisms.

The organizers of the 18th International Plant Nutrition Colloquium thank Plant and Soil for publishing this IPNC Special Issue. The next IPNC will be held in Iguazu, Brazil in 2021.

Acknowledgements PJW was supported by the Rural and Environment Science and Analytical Services Division (RESAS) of the Scottish Government. JKS and IC was supported by the University of Copenhagen and Sabanci University, respectively.

\section{References}

Abdallah HB, Mai H-J, Álvarez-Fernández A, Abadía J, Bauer P (2017) Natural variation reveals contrasting abilities to cope with alkaline and saline soil among different Medicago truncatula genotypes. Plant Soil 418:45-60 
Asif M, Tunc CE, Yazici MA, Tutus Y, Rehman R, Rehman A, Ozturk L (2018) Effect of predicted climate change on growth and yield performance of wheat under varied nitrogen and zinc supply. Plant Soil. https://doi.org/10.1007/s11104018-3808-1

Brown PH, Bellaloui N, Wimmer MA, Bassil ES, Ruiz J, Hu H, Pfeffer H, Dannel F, Römheld V (2002) Boron in plant biology. Plant Biol 4:205-223

Cakmak I (2002) Plant nutrition research: priorities to meet human needs for food in sustainable ways. Plant Soil 247:3-24

Cakmak I, Römheld V (1997) Boron deficiency-induced impairments of cellular functions in plants. Plant Soil 193:71-83

Campos P, Borie F, Cornejo P, Lopez-Raez JA, Lopez-Garcia A, Seguel A (2018) Phosphorus acquisition efficiency related to root traits: is mycorrhizal Symbiosis a key factor to wheat and barley cropping? Front Plant Sci 9:752

Carstensen A, Herdean A, Schmidt SB, Sharma A, Spetea C, Pribil M, Husted S (2018a) The Impacts of Phosphorus Deficiency on the Photosynthetic Electron Transport Chain. Plant Physiol. 177: 271-284

Carstensen A, Szameitat AE, Frydenvang J, Husted S (2018b) Chlorophyll a fluorescence analysis can detect phosphorus deficiency under field conditions and is an effective tool to prevent grain yield reductions in spring barley (Hordeum vulgare L.). Plant Soil. https://doi.org/10.1007/s11104-0183783-6

Chen X-X, Zhang W, Wang Q, Liu Y-M, Liu D-Y, Zou C-Q (2018) Zinc nutrition of wheat in response to application of phosphorus to a calcareous soil and an acid soil. Plant Soil. https://doi.org/10.1007/s11104-018-3820-5

van der Bom F, Magid J, Jensen LS (2018) Long-term fertilisation strategies and form affect nutrient budgets and soil test values, soil carbon retention and crop yield resilience. Plant Soil. https://doi.org/10.1007/s11104-018-3754-y

Ding W, Clode PL, Lambers H (2018) Is pH the key reason why some Lupinus species are sensitive to calcareous soil? Plant Soil. https://doi.org/10.1007/s11104-018-3763-x

Dwivedi SL, Ceccarelli S, Blair MW, Upadhyaya HD, Are AK, Ortiz R (2016) Landcrace germplasm for improving yield and abiotic stress adaptation. Trends Plant Sci 21:31-42

Fageria NK, Baligar VC, Jones CA (2011) Growth and mineral nutrition of field crops. CRC Press, Boca Raton, FL

Frydenvang J, van Maarschalkerweerd M, Carstensen A, Mundus S, Schmidt SB, Pedas PR, Laursen KH, Schjoerring JK, Husted S (2015) Sensitive detection of phosphorus deficiency in plants using chlorophyll a fluorescence. Plant Physiol 169:353-361

Goulding KWT (2016) Soil acidification and the importance of liming agricultural soils with particular reference to the United Kingdom. Soil Use Manag 32:390-399

Guo J, Liu X, Zhang Y, Shen J, Han W, Zhang W, Christie P, Goulding K, Vitousek P, Zhang F (2010) Significant acidification in major Chinese croplands. Science 327:1008-1010

Hallama M, Pekrun C, Lambers H, Kandeler E (2018) Hidden miners - the roles of cover crops and soil microorganisms in phosphorus cycling through agroecosystems. Plant Soil

Hao T, Zhu Q, Zeng M, Shen J, Shi X, Liu X, Zhang F, de Vries W (2018) Quantification of the contribution of nitrogen fertilization and crop harvesting to soil acidification in a wheatmaize double cropping system. Plant Soil. https://doi. org/10.1007/s11104-018-3760-0
Holland JE, Bennett AE, Newton AC, White PJ, McKenzie BM, George TS, Pakeman RJ, Bailey JS, Fornara DA, Hayes RC (2018) Liming impacts on soils, plants and biodiversity in the UK: a review. Sci Total Environ 610-611:316-332

Januszkiewicz K, Mrozek-Niećko A, Różański J (2018) Effect of surfactants and leaf surface morphology on the evaporation time and coverage area of ZnIDHA droplets. Plant Soil. https://doi.org/10.1007/s11104-018-3785-4

Johnston AM, Bruulsema TW (2014) 4R nutrient stewardship for improved nutrient use efficiency. Procedia Engineering 83: 365-370

Kekulandara DS, Sirisena DN, Bandaranayake PCG, Samarasinghe G, Wissuwa M, Suriyagoda LDB (2018) Variation in grain yield, and nitrogen, phosphorus and potassium nutrition of irrigated rice cultivars grown at fertile and low-fertile soils. Plant Soil. https://doi.org/10.1007/s11104018-3663-0

Li H, Zhang D, Wang X, Li H, Rengel Z, Shen J (2018) Competition between Zea mays genotypes with different root morphological and physiological traits is dependent on phosphorus forms and supply patterns. Plant Soil. https://doi. org/10.1007/s11104-018-3616-7

Liu GD, Dong XC, Liu LC, Wu LS, Peng S, Jiang CC (2015) Metabolic profiling reveals altered pattern of central metabolism in navel orange plants as a result of boron deficiency. Physiol Plant 153:513-524

Ma Q, Bell R, Biddulph B (2018) Potassium application alleviates grain sterility and increases yield of wheat (Triticum aestivum) in frost-prone Mediterranean-type climate. Plant Soil. https://doi.org/10.1007/s11104-018-3620-y

van Maarschalkerweerd M, Husted S (2015) Recent developments in fast spectroscopy for plant mineral analysis. Front Plant Sci 6:169

Mason SD, McLaughlin MJ, Johnston C, McNeill A (2013) Soil test measures of available P (Colwell, resin and DGT) compared with plant $\mathrm{P}$ uptake using isotope dilution. Plant Soil 373:711-722

Mueller ND, Gerber JS, Johnston M, Ray DK, Ramankutty N, Foley JA (2012) Closing yield gaps through nutrient and water management. Nature 490:254-257

Ova EA, Kutman UB, Ozturk L, Cakmak I (2015) High phosphorus supply reduced zinc concentration of wheat in native soil but not in autoclaved soil or nutrient solution. Plant Soil 393: 147-162

Pongrac P, McNicol JW, Lilly A, Thompson JA, Wright G, Hillier S, White PJ (2018) Mineral element composition of red cabbage is affected more by soil type than by phosphorus and zinc amendments. Plant Soil. https://doi.org/10.1007 /s11104-018-3628-3

Rengel Z (2015) Availability of Mn, Zn and Fe in the rhizosphere. J Soil Sci Plant Nutr 15:397-409

Richardson AE, Gupta VVSR, Alegria Terrazas R, Bulgarelli D (2017) Exploiting the root-soil microbiome for benefit to plant Nutrition In: Carstensen A, Laursen KH, Schjoerring JK (eds) Proceedings Book of the XVIII International Plant Nutrition Colloquium with Boron and Manganese Satellite Meetings. University of Copenhagen, Denmark, pp 53-54. Retrieved from: www.ipnc2017.org. Accessed 1 Oct 2018

Robles-Aguilar AA, Pang J, Postma JA, Schrey SD, Lambers H, Jablonowski ND (2018) The effect of $\mathrm{pH}$ on morphological and physiological root traits of Lupinus angustifolius treated 
with struvite as a recycled phosphorus source. Plant Soil. https://doi.org/10.1007/s11104-018-3787-2

Ryan PR (2018) Assessing the role of genetics for improving the yield of Australia's major grain crops on acid soils. Crop Pasture Sci 69:242-264

Schmidt SB, Powikrowska M, Krogholm KS, Naumann-Busch B, Schjoerring JK, Husted S, Jensen PE, Pedas PR (2016) Photosystem II functionality in barley responds dynamically to changes in leaf manganese status. Front Plant Sci 7:1772

Svenningsen NB, Watts-Williams SJ, Joner EJ, Battini F, Efthymiou A, Cruz-Paredes C, Nybroe O, Jakobsen I (2018) Suppression of the activity of arbuscular mycorrhizal fungi by the soil microbiota. ISME J 12:1296-1307

Tandy S, Mundus S, Yngvesson J, de Bang TC, Lombi E, Schjoerring JK, Husted S (2012) The use of DGT for prediction of plant available copper, zinc and phosphorus in agricultural soils. Plant Soil 346:167-180

Traenkner M, Tavakol E, Jakli B (2018) Functioning of potassium and magnesium in photosynthesis, photosynthate translocation and photoprotection. Physiol Plant 163:414-431

Wang W, Ding G-D, White PJ, Wang X-H, Jin K-M, Xu F-S, Shi L (2018) Mapping and cloning of quantitative trait loci for phosphorus efficiency in crops: opportunities and challenges. Plant Soil. https://doi.org/10.1007/s11104-018-3706-6

White PJ, Greenwood DJ (2013) Properties and management of cationic elements for crop growth. In soil conditions and plant growth, eds. P.J. Gregory and S. Nortcliff, pp. 160-
194. Oxford, U.K.: Blackwell publishing. ISBN 9781405197700

White PJ, Broadley MR, Gregory PJ (2012) Managing the nutrition of plants and people. Appl Environ Soil Sci 2012: 104826-104813. https://doi.org/10.1155/2012/104826

White PJ, George TS, Dupuy LX, Karley AJ, Valentine TA, Wiesel L, Wishart J (2013a) Root traits for infertile soils. Frontiers Plant Sci 4:193. https://doi.org/10.3389 /fpls.2013.00193

White PJ, George TS, Gregory PJ, Bengough AG, Hallett PD, McKenzie BM (2013b) Matching roots to their environment. Ann Bot 112:207-222

Wissuwa M, Kretzschmar T, Rose TJ (2016) From promise to application: root traits for enhanced nutrient capture in rice breeding. J Exp Bot 67:3605-3615

Withers PJA, Doody DG, Sylvester-Bradley R (2018) Achieving sustainable phosphorus use in food systems through circularisation. Sustainability 10:1804

Wu X, Liu G, Riaz M, Yan L, Jiang C (2018) Metabolic changes in roots of trifoliate orange [Poncirus trifoliate (L.) Raf.] as induced by different treatments of boron deficiency and resupply. Plant Soil. https://doi.org/10.1007/s11104-0183684-8

Yang W, Li P, Rensing C, Ni W, Xing S (2018) Biomass, activity and structure of rhizosphere soil microbial community under different metallophytes in a mining site. Plant Soil. https://doi.org/10.1007/s11104-017-3546-9 